\title{
A student teacher on the pathway to teaching profession: Reviewing research and proposing a model ${ }^{1}$
}

\author{
Tomáš Svatoš
}

University of Hradec Králové, Faculty of Education, Department of Pedagogy and Psychology

Received 23 July 2013; final version received 1 December 2013; accepted 6 December 2013

\begin{abstract}
There has been a long tradition of research aimed at teachers and their professional development in educational and social contexts conducted continuously by both international and Czech research community. In terms of frequency and intensity of the research interest, two areas or stages of teachers' professional development are most focused on: a novice teacher and an expert teacher. The fact that studies on future teachers and the transformation of students of teaching into teachers are only few and far between deprives teacher education, both its theory and practice, of much needed in-depth insight into these stages. This study highlights two points: Firstly, the evidence of Czech researchers' low interest in conducting research into teacher education from within, and secondly, the fact that individual stages of professional development of future teachers can be examined and described. It is particularly vital to encompass the early professional development stage when substantial changes in the attitude of beginner students of teaching to themselves as well as to teacher education and practice take place; a student role is redefined. Pointing research interest to this direction results in two outcomes. It leads to recognising a human being within a teacher student; moreover, it provides grounds for authentic and individualised interventions into students' professional development at faculties of education.
\end{abstract}

Keywords: teacher education, expert teacher, novice teacher, stages of pre-service education, student teacher, teaching profession

Inquiries into teacher profession constitute a vital part of educational research in both past and present. A teacher in one of the stages of professional development, be it a novice teacher, an advanced beginner, a competent teacher or an expert teacher (Berliner, 1995), is brought into focus of such research. These attributes depict professionals in the field of education and

1 This paper was financed by Specific research project conducted at the Department of Pedagogy and Psychology, UHK 22/07/2013.

DOI: 10.5817/PedOr2013-6-786 
skills related to education (cf. Štech, 1995), differing from one another by the quality of their teaching.

Digging deeper into the Czech educational research available, we come to conclusion that it is either the novice or expert stage of teachers' professional development that stands in the centre of interest, i.e. the utmost ends of the spectrum. The question is why it is so. There are two possible explanations. For example, as Píšová (2010) puts it, expert performance can be compared with the teaching of a novice teacher (in terms of content knowledge, methodology, teacher skills and roles). The other fact is that a growing number of supportive theories enhance insight into both professional groups. These theories not only provide background for research but also stem from it retrospectively, e.g. Schön's reflective practice model (1983), Wallace's model of applied science (1994) or Brooks and Sikes's competence-based model (1997).

However, there are differences, both fundamental and minor, between these two areas of research on teacher education. We aim to highlight dissimilarities in the examined phenomena. While the expert stage of professional development is studied by means of analyses of features of teaching in the context of cognitive as well as psychological and instructional interactions, i.e. autonomy, anticipation of situations at hand and their solutions, lesson planning, knowledge base etc. (Píšová, 2010), research into novice teachers is rather different in many respects. As Kagan (1992, In Píšová, 2010) summarises: novice teachers take the pupil variable into consideration for the first time while carrying out their teaching plans, they shift their attention from "self" to teaching and pupils, standardise educational processes used and gradually gain the ability to solve problems that may suddenly arise.

In recent studies on novice teachers the difference in their perception of developmental stages was pinpointed in three senses: me and the purpose of my pre-service education for my teaching (Urbánek, 2005), me and the conditions for my survival (Berliner, 1995; Juklová, 2009), me and my future expertise (Wiegerová et al., 2012; Chlebíková, 2013). Furthermore, there is another important attribute of research into novice teachers. In contrast to research into expert teachers, the research studies tend to aim at social and interactional aspects more as well as subjective aspects of growing into the role of a teacher (Gavora, 2008; Juklová, 2009; Chlebíková, 2013). 
The two dominant topics outlined above prove increasing interest in particular stages of one's journey towards professional role of a teacher. Nevertheless, these stages are not being examined exclusively. In this respect, Janík et al.'s review (2009) must be mentioned as it describes the field of Czech research (not only) into teacher education and proves the relevance of particular research areas as well as current trends in the presented studies. The interest in the teacher personality is further reflected in research into teacher identity (Lukas, 2007), critical incidents in the course of teacher professional development (Švaříček, 2011), or teachers at the final stages of their professional careers (Lazarová, 2011).

However, the state of the art in research conducted in the Czech Republic documents the fact that apart from intense interest in a novice and expert teacher, there is little research carried out into other stages of professional development, especially the stages of pre-service education and the pathway from a beginner student teacher on the one hand to a competent teacher on the other. There are numerous reasons why to be interested in student teachers at particular stages of their development in the course of teacher education.

Let us depict three fundamental views:

- Students' professional development progresses in gradual stages outlined in the curricula of particular degree programmes, however, the development is not linear and each student adopts their own pace (Grossmann, 1995).

- The process of teacher professional development is full of impalpable changes; research into pre-service education may aim at distinguishing identifiers of such individual changes and, subsequently, those identifiers can serve as a basis for much-needed interventions (cf. Štech, 1995).

- A parallel should be drawn between educational research and its connection with theory where theory provides background for empirical studies and subsequently stems from the results of those studies as well. Similarly, teacher education should draw from research results and, at the same time, teacher professional development ought to result from an intersection of curriculum of a degree programme on the one hand and a future teacher's potential on the other (one's presuppositions, limits, mindset etc.). 
So far the text attempted to demonstrate that in a broad context Czech research proves an interest in teacher professional development in all its stages, on the other hand, most attention is paid to the extreme poles of the teacher post-graduate professional paths. This paper aims to outline the areas of research interest in pre-service stage of teacher professional development and to answer the following questions briefly:

- What are researchers most interested in and which stages of future teachers' pre-service development are involved?

- How can research be described and how its findings can be interpreted?

- Which stages of pre-service teacher education are neglected by researchers at present?

- If, as predicted, focus should be shifted to early professional development, i.e. a future teacher as a beginner and advanced beginner student, what are the stages on the pathway to the teaching profession?

The main idea behind further description of the teacher profession through the lens of selected research studies was an observation of the change in student role in its particular stages. Let us present the following findings at this point: based on relevant resources and our knowledge of the main areas of research in the Czech context, 6 basic stages of teacher professional development were identified in teacher education:

- orientation: teacher education applicant;

- motivation: beginner student teacher;

- first redefinition: student teacher redefining his/her social-personality role;

- second redefinition: student teacher redefining his/her didactic and reflective role;

- competence: graduate;

- opening up to the profession: novice teacher.

Designation of those epistemological changes was essential in order to be able to systematise the selected examples of research into teacher education as well as to detect the intensity of research interest and its direction (Table 1). 


\section{Student teacher in research: A review}

\subsection{Procedure}

Table 1 summarises 20 examples of research studies on teacher pre-service education in order to cover the period between approximately the end of the 1990s until present. Basic criteria for the selection of the research studies ought to be presented:

(a) Examples of good research practice;

(b) covering the whole range of the six stages of teacher professional development;

(c) examples of research conducted by researchers of authority who have been long engaged in research on teacher education;

(d) representation of the time period in which the research studies were conducted;

(e) addition to a complete overview = ensuring time and content continuity in research on future teachers.

It is apparent that the selected research studies only serve as an illustration of research on pre-service teacher education as it has been a complex and dynamic process in the last two decades or so. This notion is supported by Lukášová-Kantorková's findings, for example (2003, p. 195), who analysed 9 subsequent Czech Educational Research Association conference proceedings. There she identified 525 papers altogether, out of which $35.4 \%$ were aimed at research on a teacher and teacher education conducted by 128 researchers. There are several state-of-the-art surveys, for instance by Janík $(2010 \mathrm{a}, 2010 \mathrm{~b})$ on the main points of research focus in the area of teacher education nowadays.

Our aim was to establish which stages of pre-service education the interest of particular researchers lay in and who the respondents were; the aims of the studies were depicted, research instruments described and the results presented; last but not least, theoretical background serving as a basis for the research was focused on in Table 1 (see below). 


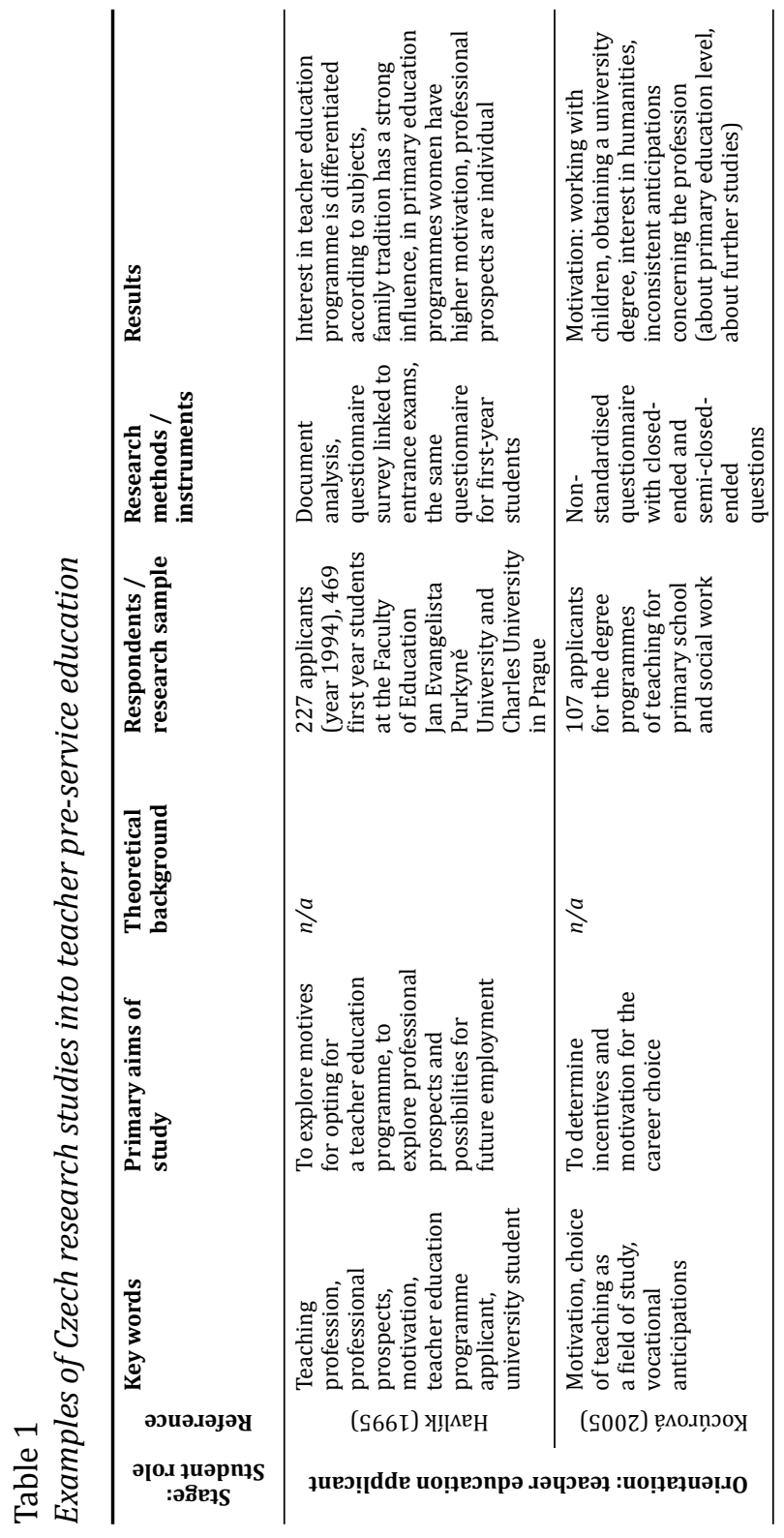




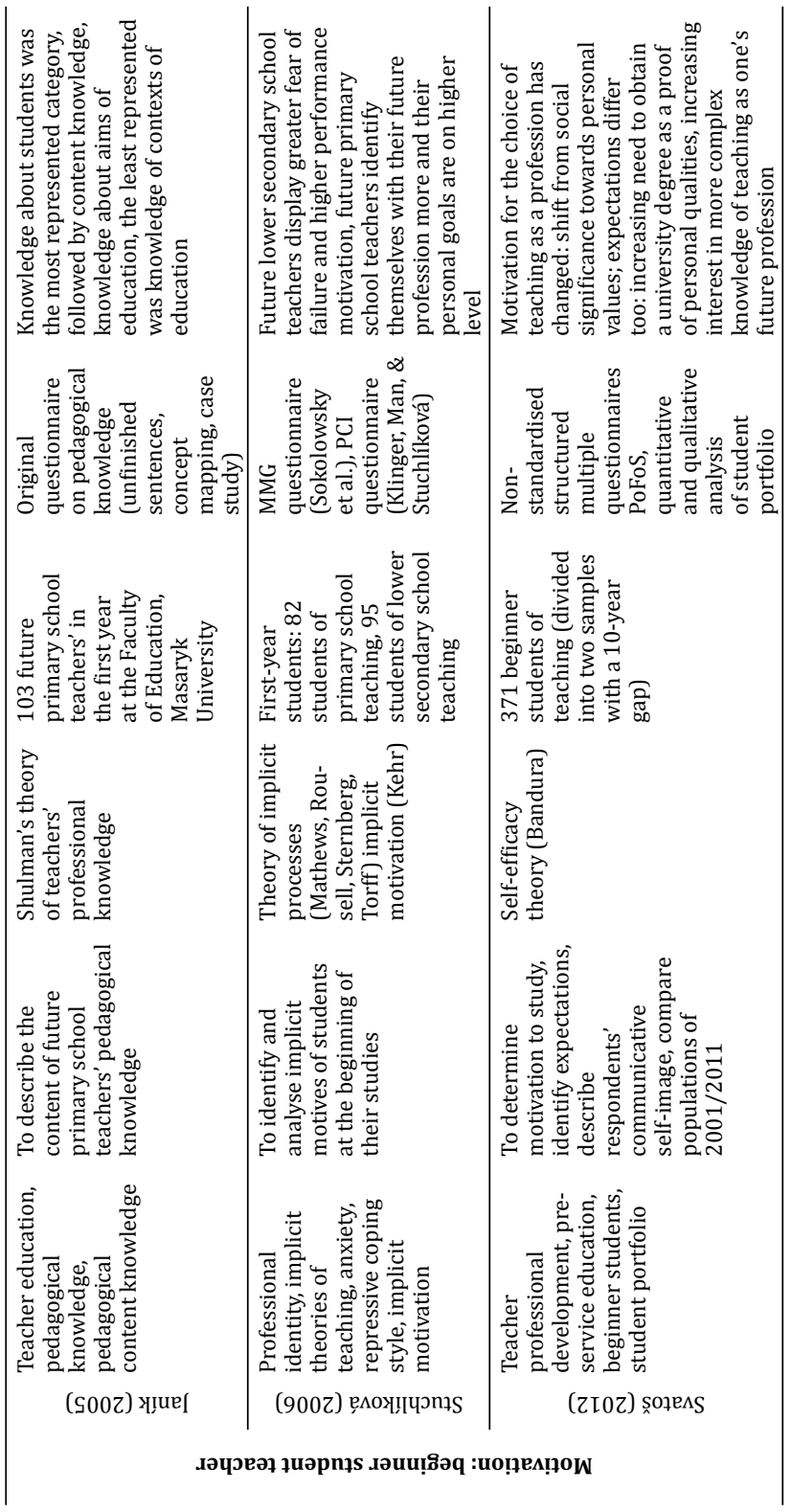




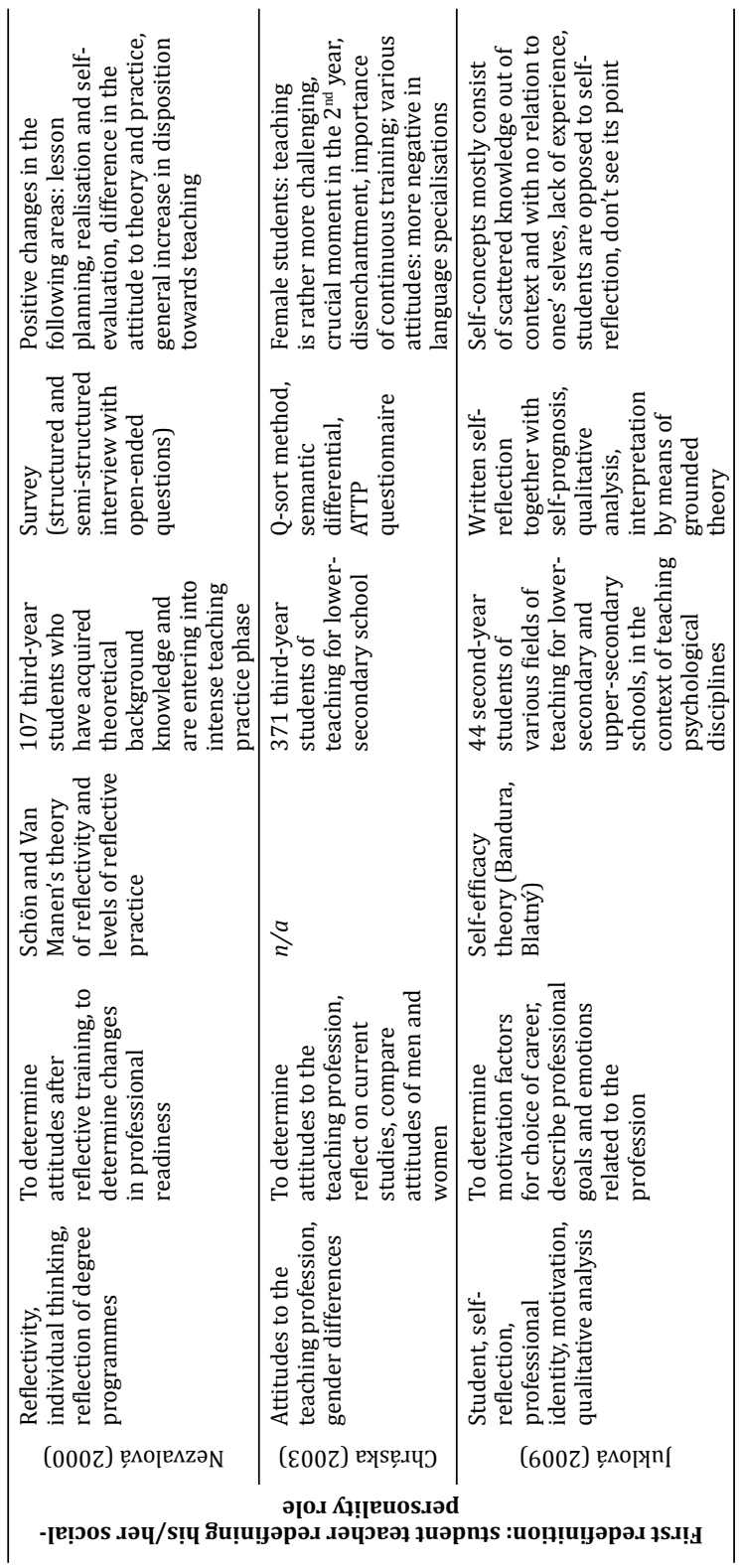




\begin{tabular}{|c|c|c|c|c|}
\hline 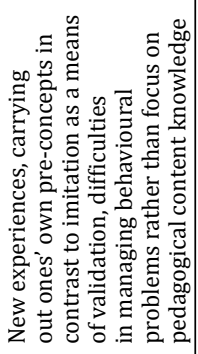 & 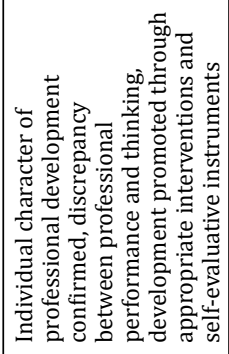 & 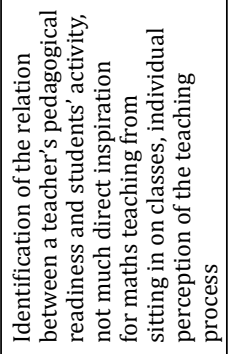 & 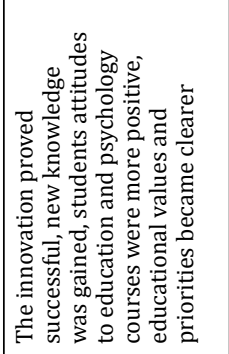 & 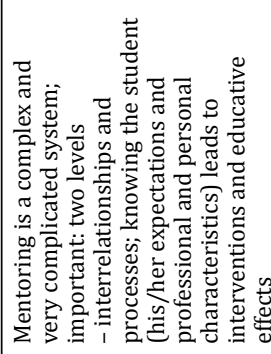 \\
\hline 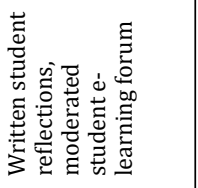 & 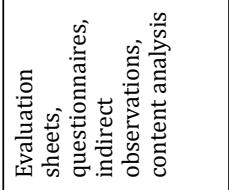 & 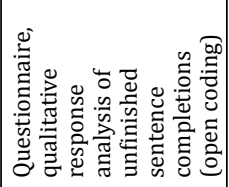 & 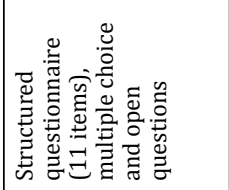 & 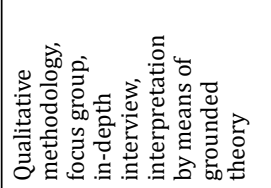 \\
\hline 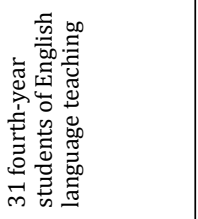 & 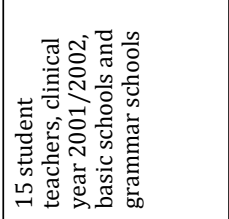 & 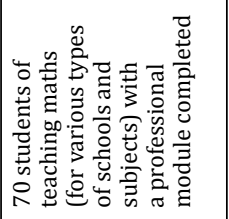 & 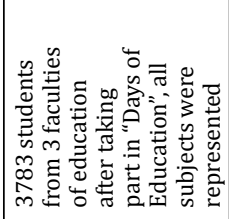 & 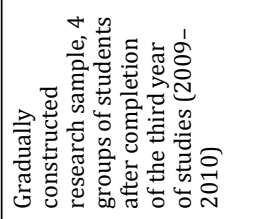 \\
\hline 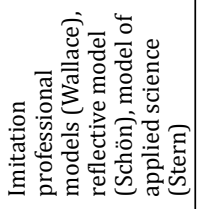 & 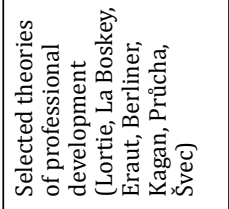 & 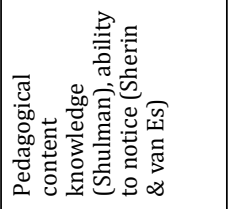 & 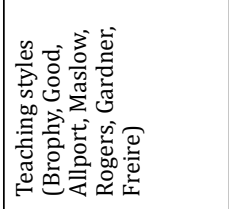 & 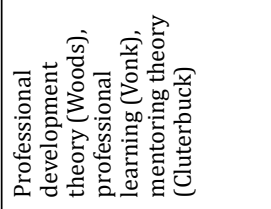 \\
\hline 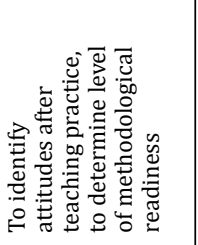 & 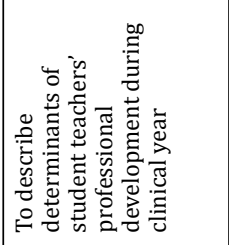 & 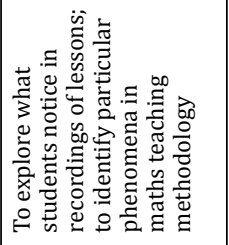 & 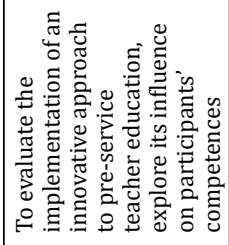 & 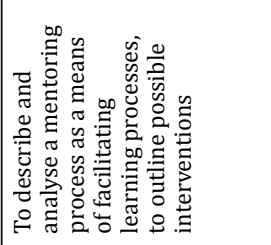 \\
\hline 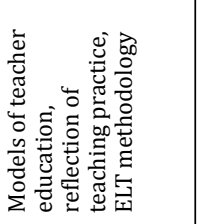 & 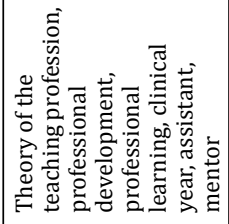 & 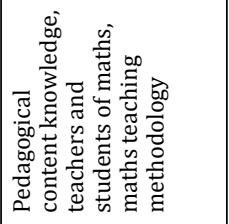 & 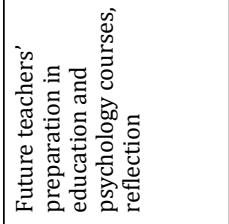 & 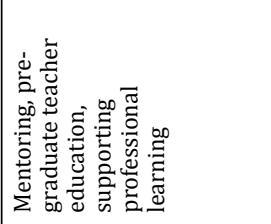 \\
\hline (s00z) ę八oşnueH & (s00z) ę八oșld & 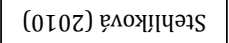 & (800z) ę八oznșe $\Lambda$ & 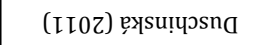 \\
\hline
\end{tabular}




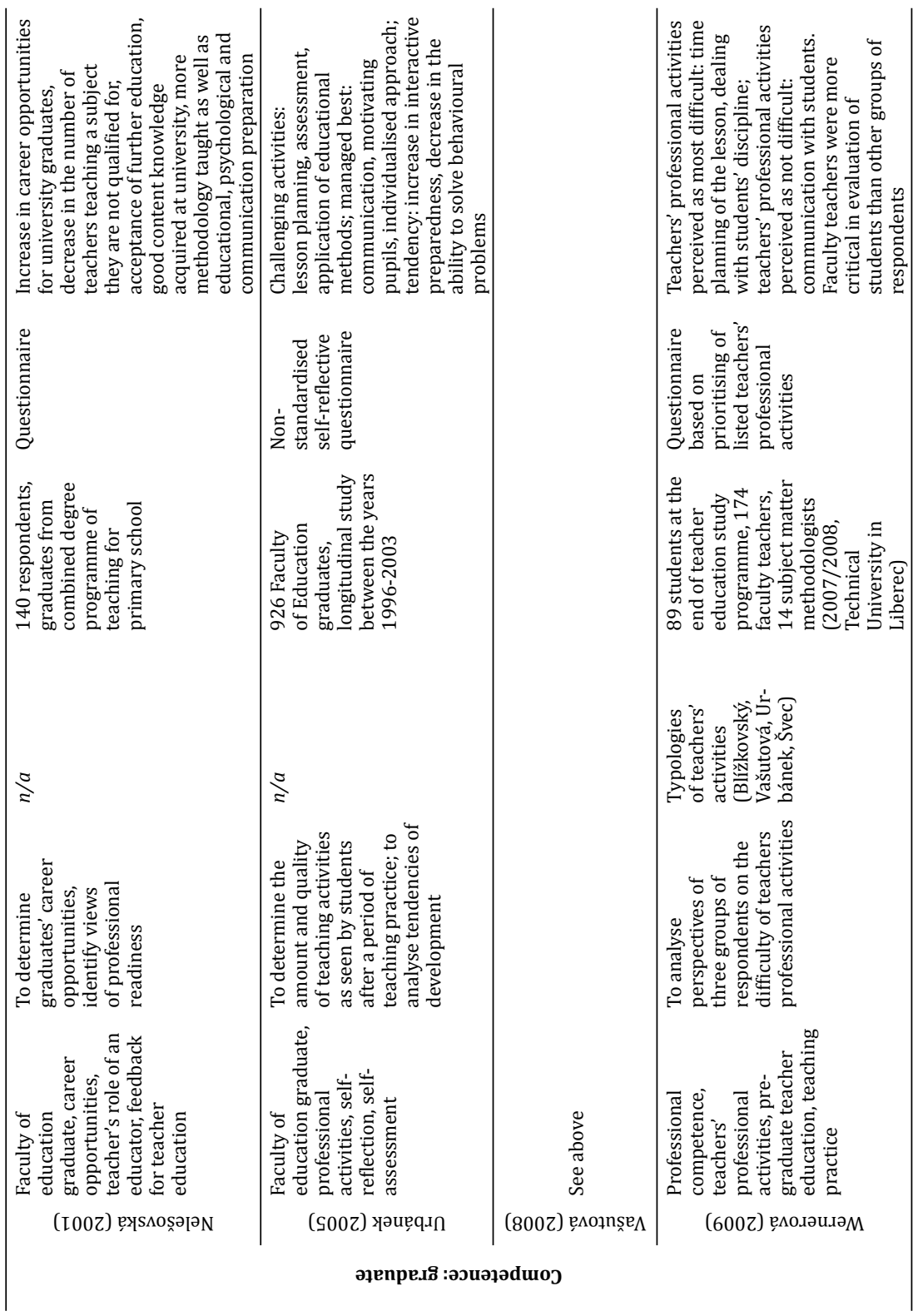




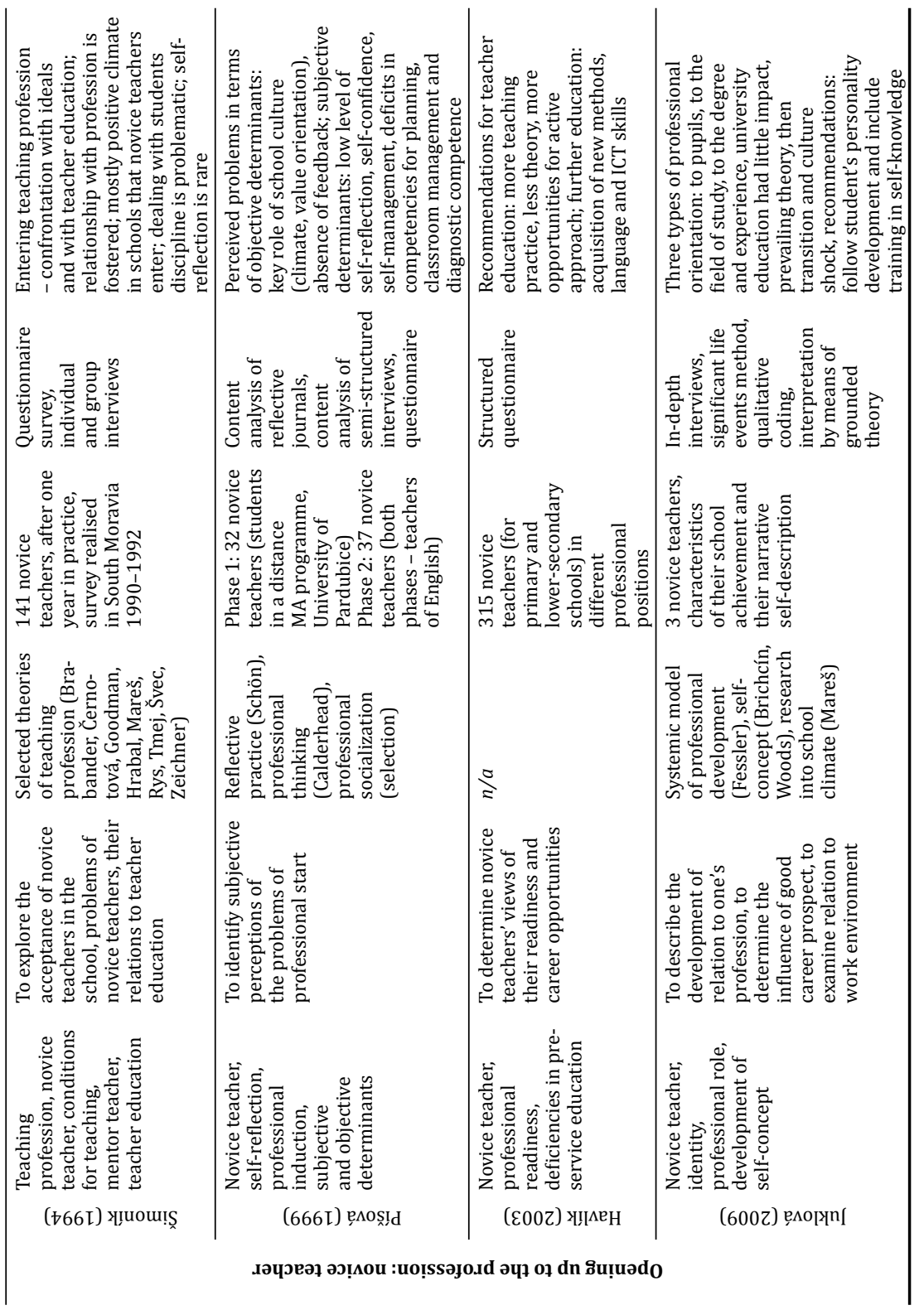




\subsection{Review outcomes}

Table 1 is not exhausting. If we take into consideration the larger scope of current state of the art though, some tendencies arise.

\subsubsection{Theoretical background}

Most empirical studies were conducted comprising regular steps i.e. describing the state-of-the-art, designating a problem and setting the aim of research, formulating hypotheses, determining methods used, data collection, formulating and answering research questions, verification of hypotheses and discussion of results and providing outlook into future research and practice. In some studies, the theoretical background was less prominent.

Hand-in-hand with the development of qualitative methodology there come the changes in not only research design but also the researchers' approach to theory. It fulfils two basic roles in current research. There is theory as the source of background knowledge, which empirical studies stem from and, vice versa, which is confronted with new findings in final stages of research. This is typical of the so-called representative research projects of various kinds (long-term projects, monographs, qualification papers such as dissertations etc.) where a theoretical fundament is considered a sine-qua-non. In other qualitative studies, theory serves as a fully-fledged part of research results, either in terms of theoretical input being elaborated on or as a new source of information arising from the empirical study (grounded theory).

The absence of research-based theory is an evident deficit of the studies we focus on. In research into teacher education, answers to the following questions would be appreciated in particular:

- What stages does a student teacher go through from the beginning of their professional development (beginner student teacher) to graduating from pre-service teacher education?

- What indicators of the individual stages of becoming a teacher can be recognised and how to understand the stages of a teacher's professional development?

\subsubsection{Research aims}

The analysis has determined that research mainly aims at two areas. It concentrates on students' attitudes and opinions at two stages of their pre- 
service education: Firstly, at the second redefinition stage where the interest lies in the assessment of a student's readiness for the teaching profession through his/her concepts of content as well as pedagogical knowledge. The other frequent group of respondents comprises graduates from faculties of education. These studies focus on the contributions and deficiencies of teacher education. They are mostly evaluative in retrospective and may serve as an inducement for adjustments in current teacher education models. What is typical of the two groups in focus is the fact that in both cases respondents are at a stage of professional development with sufficient content and pedagogical knowledge as well as the ability to make statements about themselves in order to be considered researchers' partners.

On the other hand, the remaining stages of pre-service professional development have been rarely tackled. There are several areas lacking more in-depth descriptions and analyses. At the very beginning, there are scarce data concerning who the teacher education applicants (beginner students later on) are and what their motivation, anticipations and expectations of teacher education are. At present, these studies are crucial as the number of teacher education applicants decreases and, at the same time, there is an increase in the number of difficult students who are admitted to begin teacher education without having to go through the necessary selection at entrance exams.

Research into social aspects of teacher professional development is another area that ought to be focused on as it might provide insight in to the process of teachers growing into their role (e.g. recognising changes in learning styles, understanding personal growth, determining successful or unsuccessful social interactions, overcoming high-school habits, searching for turning points in the course of professional development, etc.) Nonetheless, it is understandable that research into pedagogical knowledge and/or instructional skills of future teachers is more traditional, easier to propose and conduct, and provides better opportunities for further comparisons.

\subsubsection{Samples/respondents}

Most research studies focus on student teachers in the course or right after finishing their reflective teaching practice, i.e. when their didactic education is being tested in authentic school environment. Similarly, research into 
novice teachers' reflections on their recently finished teacher education is common.

On the other hand, research into students in early stages of their teacher education is rather scarce; particularly beginner students and the process of their establishing themselves at the faculties of education are little known about.

\subsubsection{Research methods / instruments}

In the context of current educational research it comes as no surprise that quantitative methodology of research into future teachers is often replaced by qualitative or mixed-method approach. As the research questions changed, so did the strategies and research instruments. Regarding research methods, they tend to shift from questionnaires towards in-depth interviews or focus groups, the strengths of narrative and reflective techniques are taken advantage of and a future teacher becomes the centre of attention of case studies. Last but not least, the potential that student portfolios have for research is being recognised.

The results of our analysis have shown that qualitative studies comprise minority of research into future teachers. There is no obvious answer as to why it is so. On the one hand, qualitative methodology is based on elaborate data collection and processing (e.g. open, axial and structured coding), on the other hand, application of these methods is demanding in many respects, time-consuming to say the least.

Even though technologies can be used at some stages of research (data collection and analysis of the transcribed communication in particular), it is the researcher who carries out majority of the work themselves. Since the researcher is mostly a teacher at the same time, the twofold role is even more challenging. There are several improvements crucial to enhance research into these areas such as intensive study of methodology, working with resources in foreign languages (looking up databases, making excerpts) and using technologies (mastering research software and audio-visual devices).

\subsubsection{Research findings}

It is not possible to summarise all research findings, nevertheless, three areas of results tend to stand out: 
- Results concerning a future teacher in the course of their professional development (in terms of feedback on the level of their readiness, providing a comparison of their individual level and the requirements of faculties of education).

- Results concerning the faculties of education preparing future teachers (what the contributions of the studies were, how they could become more effective; these results comprise general ideas and suggestions for improvement and supplementation of current degree programmes).

- Results concerning conceptual issues related to professional readiness of future teachers in terms of content knowledge as well as instructional skills (the analyses of students' entry into various types of graded teaching practice, investigation into the arising conceptions of teaching in relevant school subjects, description of the level of content knowledge as well as instructional skills of a student of teaching).

In summary, the focus on research into teacher education is scattered; many studies are conducted in a traditional way (especially those aiming at the second stage of pre-service education) and concentrate on analyses of content knowledge and instructional skills as well as graduates' reflections of their education.

There are gaps in our knowledge of a student on the pathway to the teaching profession, particularly in the first half of their pre-service education. This might be the reason why valid theoretical background for the early professional development stage is missing.

\section{Proposing a model of professional development stages during teacher pre-service education}

There is considerable need for designation and definition of professional development stages during pre-service teacher education. Nevertheless, state of the art in research on teacher education provides many recommendations for further exploration of the respective field, for example the works by Dytrtová and Krhutová (2009), Kasáčová (2009), Janík and Havel et al. (2005), Juklová (2008), Nezvalová (2000), Píšová (2005), Průcha (2002, 2009), Spilková (2008), Vašutová (2008) and others. However, they only serve as an initial input rather than providing a complex model. 
We consider several Czech authors' inputs essential, therefore worth mentioning at this point. Spilková (2004) has divided the development of student's professional identity into four stages: initial stage (with the intent to motivate), identification stage (preconceptions of teaching), theoreticalreflective stage (influenced by action theory and the reflection of teaching attempts), and contextual stage (with overall teaching conception set in wider context). Píšová (2005) sees the genesis of a "person in the role of a future teacher" differently as she designates three phases of future teachers' professional development: initial phase (constituted by theoretical pedagogical and psychological support, observations and teaching attempts), implementation phase (the centre of the model - the clinical year) and reflective phase (where the development can be sped up by a reflective didactic seminar).

In degree programmes at faculties of education, the topic of staging of professional development is to be found in models of increase in future teachers' readiness for teaching. For example there is the Seberová's concept of structured teaching practice segmented in gradual stages (2010). Implicitly they are included in various models of competences for specific school subjects where they are gradually and subsequently structured (Vašutová, 2001).

Based on the content of both the studies mentioned above and theoretical background summarised earlier in this study, and stemming from our expertise (for details see Svatoš, 2006, 2010, 2012), we have developed a tentative model aiming at the depiction of the trajectory of teacher professional development in the course of pre-service education and determine the stages a future teacher goes through. Considering the complexity of the topic, the proposed model only serves as a possible basis and inspiration for further examination.

\section{Adaptation stage: beginner student teachers}

The aims of teacher education

To provide conditions for adaptation and acceptance of the role of a student teacher; to lead to understanding professional development in the whole course of studies; to begin the change from a student teacher's way of thinking towards a teacher's way; to establish primary pedagogical and psychological support; to provide conditions for observation and understanding of the school reality. 
2.1 Professional development in the course of pre-service education

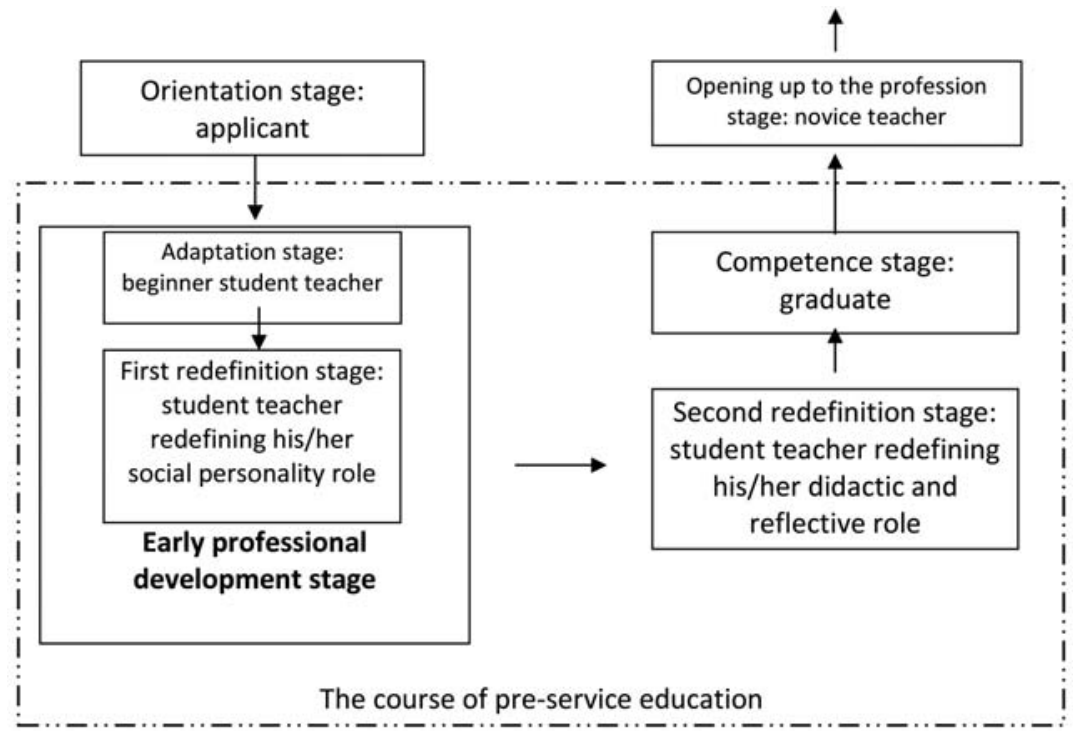

Figure 1. Model of professional development stages in the course of preservice education

\section{Indicators of professional development and socialisation}

The transition of a high-school pupil to a university student is often accompanied by euphoria and other generally positive feelings. However, during the process of getting acquainted with the student role, first problems arise. On the one hand, a student is confronted with their degree programme and the school climate; on the other hand there is a number of high-school residues and insecurities in terms of adaptation to the new environment. Their existing learning styles do not provide expected results; moreover, their habitual communication and interaction strategies prove to be ineffective. External pressure is substituted with internal one. The process of gaining independence from the family requires new family rituals and stereotypes. New peer relationships are formed and a student begins to compare their position with the others'. At that point, many a student resorts to attempts to hide in the crowd. 


\section{First redefinition stage: student teacher redefining his/her social personality role}

The aims of teacher education

To encourage a student to accept the responsibility for their studies and performance in the course of their professional development; to deepen their pedagogical and psychological way of thinking; to create a link between theoretical content knowledge and practical instructional skills assigned and practiced in tutorials; to support microteaching practice; to guide a student to habitual self-reflection and self-assessment; to pave the way to in-depth evaluation of school reality and understanding the roles of its key participants as well as their social and pedagogical interactions.

\section{Indicators of professional development and socialisation}

As beginner student teachers settle in their role, they gradually interiorise the requirements of the faculties of education. Novelty is substituted by a routine, understanding of various perspectives and contemplation whether and under what circumstances to continue studying and what kind of effort to make. A student role is redefined substantially: from an individual as a part of a study group towards a self-defining individual alongside other such persons. There is an apparent step out of the anonymous study group as students assess their future performance as teachers through the prism of selfknowledge and prediction of their own social and personal development.

\section{Second redefinition: student teacher redefining his/her didactic and reflective role}

The aims of teacher education

To establish specialist preparation as an applied field in the school education; to interlink fields of study with pedagogical transformation; to prepare the ground for consecutive opportunities for a student to act in the role of a teacher; to understand practice as a process of reflective learning - typical of teacher education; to instruct students on specific approach to education, including pupils with special needs, in the course of pedagogical and psychological preparation.

\section{Indicators of professional development and socialisation}

The second group of research studies is defined by assessment of possible future success on the basis of microteaching practice at schools. The role 
redefinition is characterised by a different approach to theory, pedagogy is applied and linked to real practical situations. Professional development brings a lot of new experience and reflective evaluations of future teachers' attempts to conduct teaching in practice sessions at real schools. Apart from theoretical content and pedagogical knowledge, a future teacher is confronted with the actual pupil social group and the educational side to teaching. It is these authentic educational problems that often lead to future teachers' self-doubt and uncertainty whether or not they will be able to manage the real stress of their future profession. This seems to be a stage full of turning points with direct impact on further professional development.

\section{Competence stage: a graduate}

The aims of teacher education

To bring future teachers to a stage where they are capable of autonomous professional conduct of expected and acceptable activities; to encourage them to evaluate their present opportunities as a result of their professional development in the course of studies and self-development (in all cognitive and specialised, psychological and pedagogical, and social and communicative aspects); to reinforce future teachers' positive self-image as it is a prerequisite of their further professional development.

\section{Indicators of professional development and socialisation}

A student of teaching becomes a graduate after fulfilling both curricular and administrative conditions required by the respective degree programme. The graduates' early assessment separates in two directions: towards reflection of recently finished studies in terms of gains and deficits on the one hand, and personal expectations, options and prognoses on the other. Personal values are influenced dominantly by personal relationships as well as confronted with the reality of career options. Finding one's way on the labour market can be accompanied by illusions and disillusionment, certainty and uncertainty, feelings of consonance or dissonance with the school as a social, professional and management environment.

\subsection{The stages of early professional development in the course of pre-service teacher education}

In the last part of our paper we will focus on a specific group of students of teaching, those who are at the very beginning of their professional pathway 
(see Table 2). We believe that this professional group, which we have been devoting our interest to recently, is neglected unfairly.

Table 2

The stages of early professional development

\begin{tabular}{|c|c|c|c|}
\hline \multicolumn{2}{|c|}{$\begin{array}{l}\text { Early stage of professional } \\
\text { development }\end{array}$} & $\begin{array}{l}\text { With respect to } \\
\text { oneself (socialising) }\end{array}$ & $\begin{array}{l}\text { With respect to } \\
\text { teacher education } \\
\text { (professionalising) }\end{array}$ \\
\hline Adaptation & & $\begin{array}{l}\text { finding one's way in } \\
\text { a heterogeneous group, } \\
\text { first expectations, } \\
\text { motivation, } \\
\text { identification of } \\
\text { changes }\end{array}$ & $\begin{array}{l}\text { missing the point of the } \\
\text { programme, behavioural } \\
\text { patterns of a high-school } \\
\text { pupil, prediction of } \\
\text { difficulties, acceptance of } \\
\text { external pressure }\end{array}$ \\
\hline \multirow{2}{*}{$\begin{array}{l}\text { First redefinition } \\
\text { stage: student } \\
\text { teacher redefining } \\
\text { his/her social } \\
\text { personality role }\end{array}$} & Comparative & $\begin{array}{l}\text { realising one's } \\
\text { possibilities and limits, } \\
\text { their projection to new } \\
\text { social interactions }\end{array}$ & $\begin{array}{l}\text { understanding of professional } \\
\text { development, requirements, } \\
\text { theory and practice }\end{array}$ \\
\hline & Convergent & $\begin{array}{l}\text { de-socialisation and } \\
\text { egocentrism, focus } \\
\text { on personal identity, } \\
\text { development at the } \\
\text { expense of a student } \\
\text { group }\end{array}$ & $\begin{array}{l}\text { beginning of interiorisation, } \\
\text { adjusting one's present } \\
\text { and future possibilities } \\
\text { and capabilities to the } \\
\text { requirements }\end{array}$ \\
\hline
\end{tabular}

\section{Why should beginner students be the focus of research?}

We are convinced that a beginner student requires both social and educational attention for numerous reasons. First of all, motivation to enter into teacher education changes from predictable motives to calculating ones (cutting oneself off from a family, extending the period of careless youth, getting a degree, winning enough time for hobbies etc.). Therefore expectations upon entry to teacher education change and there is a risk of its applicants only being passive recipients of external professional development efforts as a result of entering the education for all the wrong reasons.

In the long run it is also apparent that the faculty has to substitute for social, personal and communication deficiencies of higher secondary schools; we experience the necessity of helping beginner students to adapt in terms of encouraging them to take part in a dialogue, accept responsibility for their actions as well as the way of thinking, getting used to being assessed as well as assessing others and learning to compare one's approach and attitude to 
those of others'. Last but not least, students at the beginning of pre-service education learn to study while their habitual learning strategies acquired at high school usually prove to be ineffective and standing in the way of positive perception of the beginning of their studies. Apart from one exception, we primarily focused on social aspects of entering a faculty of education. Thus these two phases of professional development are called the first role redefinition stage in terms of social and personal development and they round off the early professional development stage (see table 2 for details).

To sum up, the main reason why beginner student teachers should be in the centre of researchers' attention is the fact that the composition of students admitted to faculties of education is changing, therefore the institutions of teacher education should react to the trend by getting to know the students and adjust the strategies and approach to their professional development accordingly.

\section{Conclusion}

Firstly, it was pointed out that current research into teacher education is intensive on the one hand, but on the other hand it is unevenly distributed in terms of research focus, instruments and results. Researchers tend to be traditionally interested in professional qualities of novice and expert teachers. As a result of our review, we find research studies into future teachers at various stages of their professional development in the course of teacher education insufficient. However, the process of adapting to the teacher role is successfully depicted in case of future teachers in the course of observed teaching practice where they apply the content knowledge as well as psychological and instructional skills acquired during their studies; moreover, studies into graduates also frequently aim at the outcomes of preservice teacher education. Unfortunately, much less is known about novice teachers who enter the professional arena and are rather interesting as their characteristics evolve in the context of social and demographic changes.

With respect to the effectiveness and authenticity of teacher education, two major conditions ought to be fulfilled: the particular stages of professional development in the course of teacher pre-service education should be described and it must be determined who the students of teaching really are. 
Both these conditions are crucial for the institutions of teacher education. If we can anticipate the professional development trajectories, fill them properly with cognitive and social content, and at the same time get to know the roles and personalities of the participants, significant potential for adjustments to current degree programmes will be uncovered. Such degree programmes will have the ambition to be considerably higher-quality and accommodating for a future teacher.

\section{References}

Berliner, D. C. (1995). Teacher expertise. In L. V. Anderson (Ed.), International encyclopedia of teaching and teacher education (pp. 46-52). Oxford: Elsevier Science Ltd.

Brooks, V., \& Sikes, P. (1997). The good mentor guide - Initial teacher education in secondary schools. Buckingham: Open University Press.

Duschinská, K. (2011). Mentoring v přípravném vzdělávání učitelů. In M. Píšová \& K. Duschinská, et al. (2011), Mentoring v učitelství (pp. 94-125). Praha: PdF UK.

Dytrtová, R., \& Krhutová, M. (2009). Učitel: Př́íprava na profesi. Praha: Grada.

Gavora, P. (2008). Učitelovo vnimanie svojej profesijnej zdatnosti (self-efficacy). Pedagogika, 58(3), 222-235.

Grossman, P. L. (1995). Teachers' knowledge. In L. V. Anderson (Ed.), International encyclopedia of teaching and teacher education (pp. 20-24). Oxford: Elsevier Science Ltd.

Hanušová, S. (2005). Reflexe v pedagogické praxi v rámci pregraduální př́ípravy učitelů anglického jazyka. In T. Janík \& T. Havel (Eds.), Pedagogická praxe a profesní rozvoj studentů (pp. 96-100). Brno: MU.

Havlík, R. (1995). Motivace k učitelskému povolání. Pedagogika, 45(2), 154-163.

Havlík, R. (2003). Postoje mladých učitelů k vlastní přípravě. In Sociální a kulturní souvislosti výchovy. 11. výroční konference ČAPV s mezinárodní účastí. Brno: Paido. [CD-ROM]

Chlebíková, A. (2013). Začínajúcí učitel' a jeho etablovanie v školskom prostredí (Dissertation thesis). Bratislava: PdF UK.

Chráska, M. (2003). Postoje k učitelské profesi v pregraduální učitelské přípravě. In Sociální a kulturní souvislosti výchovy. 11. výroční konference ČAPV s mezinárodní účastí (pp. 1-12). Brno: Paido. [CD-ROM]

Janík, T. (2005). Znalost jako klíčová kategorie učitelského vzdělávání. Brno: Paido.

Janík, T., Janíková, M., Janko, T., Knecht, P., Najvar, P., Najvarová, V., ... \& Vlčková, K. (2009). Kurikulum - výuka - školní klima - učitelské vzdělávání. Brno: MU.

Janík, T. (2010a). Integrace idejí zaměřených k profesionalizaci učitelství. Pedagogika, 60(3-4), 329-341.

Janík, T. (2010b). Stav a výhledy českého pedagogického výzkumu. Pedagogická orientace, 20(2), 5-22.

Janík, T., \& Havel, J. (Eds.). (2005). Pedagogická praxe a profesní rozvoj studentů. Brno: MU.

Juklová, K. (2008). „Jaká budu učitelka? Jaký budu učitel?”: Profesní sebepojetí studentů 2. ročníku. In T. Svatoš \& I. Loudová (Eds.), Katedra pedagogiky a psychologie se představuje (pp. 76-83). Hradec Králové: Gaudeamus UHK. 
Juklová, K. (2009). Identita začínajících učitelů (Disertační práce). Brno: FF MU.

Kasáčová, B. (2009). Učitel: Profesia a príprava. Banská Bystrica: Acta Universitatis M. Belii.

Kocúrová, K. (2005). Projekce vzdělávací a profesní cesty u studentů sociální práce a učitelství. In Pedagogický výzkum: reflexe společenských potřeb a očekávání? Sborník z XIII. konference ČAPV (pp. 123-128). Olomouc: PdF UP.

Lazarová, B. (2011). Starší učitelé (konečně) v centru pozornosti. Řízení školy, 8(7), 23-25.

Lukas, J. (2007). Vývoj učitele: přehled relevantních teorií a výzkumů. Pedagogika, 57(4), 364-379.

Lukášová-Kantorková, H. (2002). Decizní kompetence v pedagogické přípravě studentů 1. stupně základní školy. In V. Švec (Ed.), Cesty $k$ učitelské profesi: utváření a rozvíjení pedagogických dovedností (pp. 127-149). Brno: Paido.

Lukášová-Kantorková, H. (2003). Učitelská profese v primárním vzdělávání a pedagogická př́prava učitelů (teorie, výzkum, praxe). Ostrava: PedF OU.

Nelešovská, A. (2001). K některým výsledkům výzkumu „Uplatnění absolventů kombinovaného studia učitelství pro 1. stupeň ZŠ”. In Nové možnosti vzdělávání a pedagogický výzkum. Sborník z IX. celostátní konference ČAPV s mezinárodní účastí (pp. 121-124). Ostrava: PdF OU.

Nezvalová, D. (2000). Reflexe v pregraduální prrípravě učitele. Olomouc: UP.

Píšová, M. (1999). Novice teacher. Pardubice: Univerzita Pardubice.

Píšová, M. (2005). Klinický rok: Procesy profesního rozvoje studentů učitelství a jejich podpora. Pardubice: UPCE.

Píšová, M. (2010). Učitel-expert: Přehled výzkumných trendů a jejich výsledků. Pedagogika, 60(3-4), 242-253.

Píšová, M., \& Duschinská, K., et al. (2011). Mentoring v učitelství. Praha: PdF UK.

Průcha, J. (2002). Učitel: Současné poznatky o profesi. Praha: Portál.

Průcha, J. (Ed.). (2009). Pedagogická encyklopedie. Praha: Portál.

Seberová, A. (2010). Pedagogické praxe v pregraduální př́pravě učitelů 1. stupně ZŠ. Ostrava: OU.

Schön, D. A. (1983). The reflective practitioner: How professionals think in action. London: Temple Smith.

Spilková, V. (2011). Development of student teachers' professional identity through constructivist approaches and self-reflective techniques. Orbis scholae, 5(2), 117-138.

Stehlíková, N. (2010). Interpretace některých didakticko-matematických jevů u studentů učitelství a u učitelů matematiky. Pedagogika, 60(3-4), 303-313.

Stuchlíková, I. (2006). Role implicitních procesů při utváření profesní identity budoucích učitelů. Pedagogika, 56(1), 31-44.

Svatoš, T. (2006). Studentské portfolio jako zdroj poznání postojů začínajících studentů učitelství. Pedagogika, 56(1), 45-57.

Svatoš, T. (2010). Metoda focus group - př́íklad kvalitativní metodologie. Pedagogická revue, 62(1-2), 21-41.

Svatoš, T. (2012). Začínající studenti učitelství a self-efficacy. In A. Wiegerová, et al., Self-efficacy. Osobně vnímaná zdatnost (pp. 84-104). Bratislava: SPN.

Šimoník, O. (1994). Začínající učitel. Brno: PdF MU.

Štech, S. (1995). Artikulace teorie a praxe v učitelství (dilemata profese). In Teorie v pedagogické praxi, praxe v pedagogické teorii v učitelském studiu (pp. 80-83). Brno: Paido. 
Švaříček, R. (2011). Zlomové události při vytváření profesní identity učitele. Pedagogika.sk, 2(4), 247-274.

Urbánek, P. (2005). Vybrané problémy učitelské profese. Liberec: PdF TU.

Vašutová, J. (2001). Kvalifikační předpoklady pro nové role učitelů. In E. Walterová (Ed.), Učitelé jako profesní skupina, jejich vzdělávání a podpůrný system (pp. 19-46). Praha: PedF UK.

Vašutová, J. (Ed). (2007). Učitel v reflexi změn školního vzdělávání. Orbis scholae, 1(3).

Vašutová, J., et al. (2008). Vzděláváme budoucí učitele: nové prrístupy k pedagogicko-psychologické prípravě studentů učitelství. Praha: Portál.

Wallace, M. J. (1994). Training foreign language teachers. A reflective approach. Cambridge: CUP.

Wernerová, J. (2009). Obtížnost profesních činností učitele z pohledu studentů učitelství, učitelů a oborových didaktiků. Pedagogická orientace, 19(3), 107-116.

Whitte, B. (2000). Pre-service teachers' epistemology viewed through perspectives on problematic classroom situations. Journal of Education for Teaching, 26(3), 279-305.

Wiegerová, A., et al. (2012). Self-efficacy. Osobně vnímaná zdatnost v edukačních souvislostech. Bratislava: SPN.

\title{
Author
}

Tomáš Svatoš, University of Hradec Králové, Faculty of Education, Department of Education and Psychology, Rokitanského 62, 50003 Hradec Králové, e-mail: Tomas.Svatos@uhk.cz

\section{Student na cestě $\mathbf{k}$ učitelství - inspirace $\mathrm{z}$ výzkumné praxe}

\begin{abstract}
Abstrakt: Výzkumy věnované učiteli, jeho profesnímu vývoji v edukačních i sociálních souvislostech mají dlouho tradici a jsou v nejen v českém výzkumném prostředí neustále obohacovány novými badatelskými podněty. Intenzitou, ale také četností se výzkumný zájem soustředí především do dvou profesních stádií: směrem k poznání začínajícího učitele a popisu učitele-experta. Je ke škodě pedeutologické teorie i praxe, že bádání jen $\mathrm{v}$ některých případech směřují k pregraduální přípravě a poznávání proměn studenta v budoucího učitele. Předkládaná stat' poukazuje na dvě okolnosti: první - potvrzující zmiňovanou skutečnost o menším zájmu českých badatelů o výzkumy „uvnitř̆“ učitelského vzdělávání, a druhou - že je možné popsat vývojové profesionalizační etapy v pregraduální přípravě a také je výzkumně ověřovat. Zvláště významné je to $\mathrm{v}$ období tzv. ranné profesionalizace, kdy dochází k podstatným změnám v postojích začínajících studentů učitelství k sobě samému, učitelskému vzdělávání i pojetí edukační praxe (dochází k redefinování studentské role). Zvýšení badatelského zájmu tímto směrem má dva významné efekty: především vede k poznávání „člověka v roli studenta učitelství" a současně dává instituci učitelského vzdělávání př́iležitost $\mathrm{k}$ autentickým a individuálně zaměřeným intervencím.
\end{abstract}

Klíčová slova: pedeutologické výzkumy, učitel-expert, začínající učitel, etapy pregraduálního vzdělání, redefinice studentské role, raná profesionalizace 